\title{
POLA KOMUNIKASI KONSELOR DAN NARAPIDANA
}

\author{
Arif Wibawa, Yenni Sri Utami, dan Siti Fatonah \\ Program Studi Ilmu Komunikasi FISIP UPN “Veteran” Yogyakarta, \\ Jl. Babarsari No. 2, Tambakbayan Yogyakarta, Telp: (0274) 485268, 485990 \\ Email: info@upnyk.ac.id
}

\begin{abstract}
This study aims to find an effective communication model counselor in Narcotics Prison of Class IIA Sleman Yogyakarta in rehabilitating drug users. This study uses qualitative method for its ability to help clarify the picture of the development of models of effective communication patterns counselor Narcotics Prison Class II A Sleman Yogyakarta in rehabilitating drug users. The research found that the pattern of communication and coaching in the rehabilitation of drug users in Narcotic Prison of Class II A Sleman Yogyakarta consists of two patterns. The first is informal and formal communication patterns. The second concept is carried out by community terapeutic concept, a method aimed for the social rehabilitation for victims of drug users. This patterns aimed at forming prisoners in to a human who returned intact after dependence on drugs, fostering awareness of the law, reintegration in to society, job skills training, and counseling and rehabilitation programs. Keywords: effective communication, counselors, rehabilitation, drugs prisoners
\end{abstract}

\begin{abstract}
Abstrak
Penelitian ini bertujuan untuk menemukan model komunikasi efektif konselor di lapas Narkotika Kelas II A dalam merehabilitasi narapidana narkoba. Penelitian ini menggunakan metode kualitatif karena kemampuannya untuk membantu memperjelas gambaran pengembangan model pola komunikasi efektif konselor Lapas Narkotika Kelas II A Sleman Yogyakarta dalam merehabilitasi warga binaan narapidana narkoba. Hasil penelitian ini menemukan pola komunikasi dan pembinaan dalam rehabilitasi pengguna narkotika di lapas Klas II A Yogyakarta terdiri dari dua pola. Pertama, pola komunikasi informal dan pola komunikasi formal. Konsep kedua yang dilakukan adalah dengan konsep terapeutic community, suatu metode rehabilitasi sosial yang ditujukan kepada korban penyalahguna napza. Konsep ini masih baru dikembangkan di Lapas Klas II A Yogyakarta. Pola komunikasi yang telah berhasil diidentifikasi bertujuan membentuk warga binaan menjadi manusia yang kembali utuh setelah ketergantungannya terhadap narkoba, pembinaan kesadaran hukum, reintegrasi warga binaan dengan masyarakat, pembinaan keterampilan kerja, dan bimbingan konseling serta program rehabilitasi.
\end{abstract}

Kata kunci: Model Komunikasi konselor, rehabilitasi, narapidana narkoba

\section{Pendahuluan}

Masalah penyalahgunaan narkoba saat ini semakin meluas dan telah menjadi keprihatinan bangsa. Banyak nilai kemanusiaan yang dihancurkan karena narkoba. Sepanjang tahun 2013, kasus penyalahgunaan narkoba di wilayah hukum DIY meningkat dibanding tahun sebelumnya. Berdasarkan data di Direktorat Reserse Narkoba (Ditresnarkoba)PoldaDIY, sampaidengan pertengahan Desember 2013 total kasus yang ditangani 317. Sedangkan tahun 2012, penanganan perkara tercatat 258 . Berdasar hasil analisa dan evaluasi yang dilakukan Direktorat Reserse Narkoba atau Ditresnarkoba beserta jajarannya, pada tahun 2013 ini kasus kejahatan narkotika di DIY mengalami lonjakan peningkatan di banding kasus yang ditangani tahun 2012 silam. Sebanyak 40.057 tersangka narkoba diamankan sepanjang 2013. (http:/ / nasional.republika. co.id/berita/nasional/jawa-tengah-diynasional/13/12/30/, akses 12 Maret 2014).

Jumlah penyalahgunaan narkoba di Indonesia mengalami peningkatan dari waktu ke waktu. Hasil penelitian tahun 2008 jumlah penyalahguna narkoba mencapai 3,3 juta orang. Kemudian tahun 2011 menjadi 3,8 juta 
orang dan di 2013 mencapai lebih dari 4 juta orang. Penyalahgunaan narkoba telah menyentuh angka 4 juta jiwa atau 2,2 persen dari seluruh penduduk Indonesia sepanjang 2013 ini. (http://news.okezone. com/read/2014/01/23/337/930885, akses 23 Maret 2014).

Kasus narkoba terus meningkat, Kepolisian Negara Republik Indonesia (Polri) selama tahun 2012 menangani 26.561 kasus narkoba dan telah terselesaikan 22.822 kasus atau 81 persen, sehingga 3.739 kasus masih menjadi tunggakan atau 19 persen pada 2013. Barang bukti yang diamankan yakni ganja kering sebanyak 21.000 kilogram, lahan ganja seluas 88 hektare, heroin sebanyak 34.000 gram, ekstasi sebanyak 2,8 juta butir dan sabu-sabu sebanyak 1,9 ton. Berdasarkan data Bureau for International Narcotics and Law Enforcement Departemen Luar Negeri AS, jumlah transaksi yang dihasilkan dari peredaran narkoba di Indonesia sangat fantastis, yakni mencapai Rp300 triliun per tahun. (http://www. antaranews.com/berita/349418/polriungkap-26561, akses 02 Januari 2013).

Tingkat pengguna narkoba dari tahun ke tahun semakin mengkhawatirkan, terutama di kalangan pelajar dan mahasiswa. Menurut data dari Badan Narkotika Nasional (BNN), pengguna narkoba tahun 2013 sudah mencapai 3,8 juta. Jumlah ini meningkat dibanding tahun sebelumnya sebesar 3,6 juta. 22\% diantaranya, berasal dari kalangan pelajar dan mahasiswa. Narkoba jenis ganja, ekstasi maupun shabu-shabu menjadi favorit di kalangan ini. Musuh besar yang dihadapi bangsa ini adalah bahaya narkoba, karena sekitar 50 persen dari 135.000 penghuni lembaga pemasyarakatan di Inonesia adalah pengguna narkoba. Jika hal ini dibiarkan, maka sama saja akan menghancurkan masa depan generasi. (http://www.bnn.go.id/ artikel/11535/ narkoba, akses 20 April 2014).
Mengingat dampak narkoba yang sifatnya merusak dan mematikan, menghambat tujuandalammenciptakangenerasi yang berkualitas. Tidak hanya secara medis maupun psikis saja, tetapi juga merambah pada lingkungan masyarakat sekitarnya. Seperti mempengaruhi dunia pendidikannya, interaksi sosial keluarga, juga masyarakatnya. Untuk itu, perlu langkah konkrit dalam menekan jumlah pengguna narkoba.

Upaya dalam menyelesaikan permasalahan narkoba di Indonesia sudah banyak dilakukan, terutama oleh para penegak hukum. Namun sampai saat ini pengguna narkoba belum berkurang bahkan cenderung bertambah. Nampaknya permasalahan narkoba adalah suatu masalah yang pelik baik dilihat dari penyebarannya maupun penangannya. Narkoba tidak hanya beredar diluar penjara saja, tetapi di dalam penjara pun para bandar itu masih aktif berbisnis racun itu. Seorang mantan napi tipikor mengatakan kepada penulis, narapidana narkoba biasanya paling enak hidupnya di penjara, karena mampu membayar, dia sumber pemerasan, setelah itu baru narapidana tipikor. Salah satu hal yang menyebabkan permasalahan tersebut belum dapat diselesaikan adalah pandangan masyarakat terhadap pengguna narkoba yang masih dicap sebagai pelaku kejahatan, sampah masyarakat, dan berbagai stigma negatif lainnya, sehingga mereka harus dihukum penjara.

Mayoritas penghuni lapas dan rutan didominasi oleh tahanan kasus narkoba. Di Indonesia ini jumlahnya rata-rata mencapai 30 persen. Lapas Narkoba Yogyakarta berkapasitas 474 orang dan saat ini dihuni 83 narapidana. Sementara secara keseluruhan jumlah narapidana dan tahanan narkoba di Provinsi Daerah Istimewa Yogyakarta sebanyak 295 orang. Yogyakarta menjadi daerah 
yang dipilih pembangunan Lapas Narkoba pertama karena jumlah tahanan dan narapidana kasus narkobanya tergolong cukup tinggi. (http://www. tempo.co/read/news/2009/04/28)

Menjadiironiadalahmasihterbatasnya jumlah korban penyalahgunaan narkoba yang mendapatkan layanan terapi dan rehabilitasi. Tercatat hanya sekitar 0,47 persen atau sekitar 18.000 orang dari angka 4 juta yang dapat direhabilitasi. Kondisi tersebut disebabkan karena kurangnya jumlah tempat rehabilitasi bagi penyalah guna narkoba yang dimiliki oleh pemerintah maupun swasta, disamping masyarakat belum punya budaya untuk melaksanakan rehabilitasi secara sukarela. (http://dedihumas.bnn.go.id/ $\mathrm{read} / \mathrm{section} /$ berita/2013/07/25/708/ semangat-bersama, akses 24 Maret 2014)

Kebijakan pembinaan narapidana narkoba merupakan masalah yang sangat kompleks, karena yang terlibat adalah pengedar dan pengguna. Kompleksitas tersebut karena narapidana yang masih tergantung narkoba, sehingga perlu penyembuhan secara medis dan mental (rehabilitasi medis dan mental). Kebijakan pembinaan narapidana khusus narkotika berbeda dengan penanganan narapidana pada umumnya sehingga dalam pembinaan perlu didasari dengan metode sistematis dan strategi yang tepat, baik terhadap pengedar maupun pengguna narkoba. Karena narapidana narkoba tidak hanya menjalani pidana, namun juga perlu direhabilitasi, agar terbebas dari belenggu narkoba.

Kebijakan program pembinaan narapidana mengacu pada Pola Pembinaan Narapidana/Tahanan yang merupakan Keputusan Menteri Kehakiman Nomor: M.02-PK.04.10 Tahun 1990 dan Peraturan Pemerintah Nomor 31 tahun 1999 tentang Pembinaan dan Pembimbingan Warga Binaan Pemasyarakatan (WBP). Pelaksanaan kebijakan program ini disesuaikan dengan situasi dan kondisi yang ada pada Lapas setempat, yang melibatkan unsur masyarakat, pemerintah, dan keluarga WBP. Kedua kebijakan pembinaan narapidana tersebut merupakan pola pembinaan narapidana umum.

Komunikasi dalam Lembaga Pemasyarakatan merupakan bagian penting dari proses pembinaan untuk mencapai berbagai sasaran baik itu komunikasi interpersonal maupun komunikasi kelompok yang sering diterapkan dalam Lembaga Pemasyarakatan. Pendekatan melalui bentuk-bentuk komunikasi yang persuasif akan lebih efektif untuk membina prilaku dari setiap warga binaan agar tidak mengulangi perbuatan yang sama. Dalam sistembaru pembinaannarapidana, terdapat perubahan orientasi pembinaan dari top down approach menjadi bottom up approach. Orientasi top down approach menganggap bahwa narapidana hanya sebagai obyek semata-mata. Jadi sebagai obyek, eksistensi narapidana untuk ikut serta membangun dirinya kurang diperhatikan. Sedangkan bottom up approach, merupakan orientasi pembinaan narapidana berdasarkan kebutuhan belajar.

Komunikasi interptersonal yang efektif adalah adanya kesepakatan informasi serta kualitas hubungan yang dibangun. Kedua belah pihak perlu membangun hubungan yang lebih baik, karena ketepatan penyampaian informasi ditentukan oleh pengertian, pengaruh sikap, hubungan yang makin baik serta tindakan. Moekijat menjelaskan bahwa: "Komunikasi yang efektif mengandung pengiriman dan penerimaan informasi yang paling cermat, pengertian pesan yang mendalam oleh kedua pihak dan pengambilan tindakan yang tepat terhadap penyelesaian pertukaran informasi.". (Moekijat, 1993:146)

Karakteristik komunikasi Interpersonal yang efektif dilihat dari 
sudut pandangnya dibagi menjadi tiga sudut pandang, yaitu: 1) Sudut pandang Humanistik, pandangan ini bias disebut sebagi pandangan yang lunak. "Menekankan pada keterbukaan, empati, sikap mendukung, dan kualitas-kualitas lain yang menciptakan interaksi yang bermakna, jujur dan memuaskan". 2) Sudut pandang Pragmatis, menekankan pada manajemen dan kesegaran interaksi. secara umum kualitaskualitas yang menentukan pencapaian tujuan yang spesifik, sudut pandang ini biasanya dinamakan dengan model kompetensi karena memusatkan pada perilaku spesifik yang harus digunakan oleh komunikator untuk mendapatkan hasil yang diinginkan. 3) Sudut pandang pergaulan sosial dan kesetaraan, mengacu pada konsep DeVito, tentang Komunikasi interpersonal yang efektif dari sudut pandang humanistik, "Untuk menghasilkan komunikasi yang efektif diperlukan adanya keterbukaan, sikap empati, sikap mendukung, sikap positif serta kesetaraan dari pihak-pihak yang berkomunikasi". (DeVito, 2010:259-261)

Efektivitas komunikasi antar personal dalam pandangan humanistik mengandung unsur-unsur sebagai berikut:a) Keterbukaan, mengisyaratkan para pihak bersedia menerima kritikkritik dan saran yang disampaikan dalam komunikasi tersebut. Kualitas keterbukaan mengacu pada sedikitnya tigaaspek darikomunikasi antar personal. Pertama, komunikasi interpersonal yang efektif harus terbuka kepada orang yang diajaknya berinteraksi. Ini tidak berarti bahwa orang harus dengan segera membukakan semua riwayat hidupnya. Harus ada kesediaan membuka diri mengungkapkan informasi yang biasanya disembunyikan, asalkan pengungkapan diri ini patut. Kedua, mengacu pada kesediaan komunikator untuk bereaksi secara jujur terhadap stimulus yang datang. Aspek ketiga menyangkut "kepemilikan" perasaan dan pikiran.

b) Empati, merupakan kemampuan seseorang untuk mengetahui apa yang sedang dialami orang lain pada suatu saat tertentu, dari sudut pandang orang lain melalui kaca mata orang lain. "Berempati adalah merasakan sesuatu seperti orang yang mengalaminya". (DeVito, 2010: 260).

c) Sikap Mendukung (Supportiveness), hubungan interpersonal yang efektif adalah hubungan di mana terdapat sikap mendukung (supportiveness). Sikap suportif merupakan sikap yang mengurangi sikap defensif. Sikap ini muncul bila individu tidak dapat menerima, tidak jujur dan tidak empatik. Sikap defensif mengakibatkan komunikasi interpersonal menjadi tidak efektif.

d) Sikap Positif, sikap positif mengacu pada sedikitnya dua aspek komunikasi antar personal. Pertama, komunikasi interpersonal terbina jika orang memiliki sikap positif terhadap diri mereka sendiri. Orang yang merasa positif terhadap diri sendiri mengisyaratkan perasaan tersebut kepada orang lain dan merefleksikannya. Kedua, perasaan positif untuk situasi komunikasi sangat penting untuk interaksi yang efektif.

e) Kesetaraan (Equality), keinginan yang secara eksplisit diungkapkan untuk bekerja sama memecahkan masalah tertentu. Komunikasi interpersonal akan lebih efektif bila ada persamaan antara pihak-pihak yang terlibat dalam komunikasi, maka mereka dapat saling menghargai dan menghormati perbedaan pandangan.

Menurut Sudjana (2000: 28) ada tiga pola komunikasi yang dapat digunakan untuk mengembangkan interaksi dinamis dalam upaya memunculkan penyadaran, yaitu : 1) Komunikasi sebagai aksi atau komunikasi satu arah, komunikator berperan aktif sebagai pemberi aksi 
dan komunikan sebagai penerima aksi. Bentuk ini adalah ceramah yang pada dasarnya adalah komunikasi satu arah. 2) Komunikasi sebagai interaksi atau komunikasi dua arah, komunikator dan komunikan dapat berperan sama yakni pemberi aksi dan penerima aksi. Keduanya dapat saling memberi dan saling menerima. 3) Komunikasi banyak arah atau komunikasi sebagai transaksi, komunikasi tidak hanya melibatkan interaksi dinamis antara komunikator dan komunikan tetapi juga dapat melibatkan interaksi dinamis antara unsur-unsur komunikan lainnya.

Model komunikasi transaksi memberi tekanan pada proses dan fungsi untuk berbagi dalam hal pengetahuan dan pengalaman. Komunikasi sebagai proses di mana semua peserta ikut aktif secara dinamis dalam memenuhi fungsi sosial sebagai anggota masyarakat (Cangara, 2004: hal. 27).

Komponen komunikasi transaksi menurut Sereno dan Bodaken (1975) dalam Mulyana (2010: 67-74) adalah persepsi, sistem, arti dan proses. Persepsi merupakan pemrosesan terhadap stimuli internal dan eksternal. Komunikasi sebagai proses dinamis yang menimbulkan perubahan pada pada para peserta komunikasi. Seluruh komponen tersebut saling berhubungan dan dijalankan bersama dalam setiap situasi komunikasi.
Perspektif perbedaan individu memandang bahwa sikap dan organisasi personal psikologis (dalam arti faktorfaktor yang ada dalam diri individu) akan menentukan bagaimana individu memilih stimuli dari lingkungan dan bagaimana ia memberi makna pada stimuli tersebut (Effendy, 1996:56). Perspektif ini bisa digunakan untuk menjelaskan bagaimana faktor individu (karakteristik) orang menentukan pola komunikasi yang digunakannya.

Di samping faktor individu, faktor lingkungan juga tidak bisa diabaikan. Karena para pembina lapas kelas IIA dalam kesehariannya bersama para warga binaan narapidana narkoba selalu berinteraksi dengan lingkungan sosial. Sehingga pola-pola komunikasi yang terjadi dipengaruhi pula oleh lingkungan sosial tersebut. Hal ini diperkuat oleh pendapat Festinger (1957) dalam Ramdhani (2006) bahwa perilaku manusia tergantung dari pengetahuan, opini, apa yang dipercaya orang mengenai lingkungan dan mengenai diri sendiri. Jadi dalam melakukan pembinaan terhadap narapidana narkoba menggunakan suatu jenis pola komunikasi ditentukan baik oleh faktor individu maupun faktor lingkungan.

Lembaga Pemasyarakatan adalah ujung tombak pembinaan narapidana yang dilaksanakan melalui pendidikan, rehabilitasi dan reintegrasi. Pembinaan
1

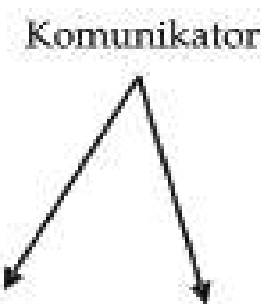

2

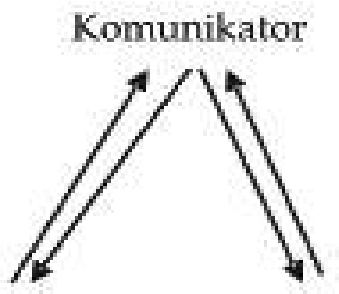

3

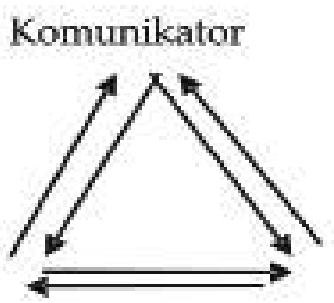

Komunikan Komunikan Komunikan Komunikan Komunikan Komunikan

Gambar 1. Model Komunikasi Transaksi 
narapidana akan berjalan lancar apabila ditunjang oleh berbagai aspek baik sarana maupun prasarana yang memadai. Seorang tahanan dan narapidana perlu dibimbing dan dibina melalui proses pendidikan, dan diberdayakan dalam upaya rehabilitatif serta reintegrasi. Proses pembinaan dan pemberdayaan inilah yang menjadi titik fokus dan metode yang diterapkan dalam pemasyarakatan sebagai upaya dalam memperkecil terjadinya tindak kejahatan kembali. Menurut Soerjobroto (1994:27).

Masyarakat luas mengenal istilah Narkotika yang kini telah menjadi fenomena berbahaya yang populer di tengah masyarakat kita. Ada pula istilah lain yang kadang digunakan adalah Narkoba (Narkotika dan obat-obatan berbahaya). Selain itu ada pula istilah yang digunakan oleh DepKes RI yaitu NAPZA merupakan singkatan dari Narkotika, Pasikotropika dan Zat adiktif lainnya. Narkotika dan Psikotropika itulah yang secara umum biasa di kenal dengan Narkoba atau NAPZA. Namun karena hadirnya Undang-Undang Nomor 35 Tahun Tentang Narkotika yang baru, maka beberapa pengaturan mengenai psikotropika dileburkedalam perundangundangan yang baru.

\section{Metode Penelitian}

Metode yang digunakan dalam penelitian ini adalah penelitian kualitatif. Penelitian ini menggunakan pendekatan kualitatif-diskriptif, karena kemampuannya untuk membantu memperjelas gambaran penerapan model komunikasi para konselor Lembaga Pemasyarakatan Narkotika Kelas II A Sleman Yogyakarta terhadap warga binaan tidak cukup dengan pendekatan kuantitatif. Dengan ciri serta prinsip diatas, maka metode ini dipilih. Penelitian ini sangat mengedepankan peneliti untuk belajar bersama dengan masyarakat dan kemudian penelitian akanmenjadikankomunitas beraktifitas sadar dengan pengetahuan mereka tentang pentingnya pengembangan model komunikasi yang lebih efektif untuk diterapkan pihak Lembaga Pemasyarakatan Narkotika Kelas II A Sleman Yogyakarta terhadap warga binaan narapidana narkoba.

Subjek yang dijadikan bahan penelitian ini adalah para narapidana di Lembaga Pemasyarakatan Narkotika kelas II A Sleman, Yogyakarta. Peneliti akan mengambil informan dengan beragam baik dari sisi lama masa tahanan, usia, pendidikan dan tempat asal. Unit analisisnya adalah individu. Informasi dari individu akan dijaring melalui wawancara mendalam (indepth interview).

Objek penelitian ini adalah kegiatan pembinaan narapidana di Lembaga Pemasyarakatan

Narkotika kelas II A Sleman Yogyakarta. Kegiatan narapidana ini dibagi menjadi dua, yaitu pembinaan dengan pendekatan umum, serta yang dilakukan dengan pendekatan individual. Dalam pembinaan dengan pendekatan umum, narapidana diberikan bekal keterampilan dan pendidikan yang cukup agar kelak siap kembali dalam kehidupan bermasyarakat. Sedangkan dalam pembinaan dengan pendekatan individual dilakukan melalui konseling pribadi yang sifatnya interpersonal komunikasi yang dijalankan konselor dalam menangani para narapidana di lapas kelas II A Sleman, Yogyakarta.

Sumber data yang digunakan dalam penelitian ini berupa; a) Data Primer, merupakan data yang diperoleh secara langsung dari informan yakni pengurus lapas, petugas konselor dan para narapidana di lapas kelas II A Sleman, Yogyakarta. Data yang didapat dari informan tersebut berwujud hasil hasil survey, rekaman wawancara, hasil pengamatan dan catatan lapangan. b) 
Data sekunder, merupakan data yang diperoleh dari sumber lain seperti arsip, dokumen, kepustakaan, data statistik dan lain-lain yang digunakan untuk mendukung penelitian.

Tahapan Penelitian kemudian dilakukan dengan metode multiangulasi yang melibatkan beberapa metode, yaitu: studi pustaka atau literature, wawancara (indept interview), diskusi kelompok terarah (Focus Group Discussion), dan observasi lapangan. Analisis data dalam penelitian ini dilakukan untuk mengungkap dan menggambarkan pola komunikasi konselor narapidana dalam menjalankan peranannya menangani para warga binaan di Lembaga Pemasyarakatan Kelas II A Yogyakarta serta tantangan yang dihadapinya.

\section{Hasil dan Pembahasan}

\section{Deskripsi Objek Penelitian}

Saat ini Lapas narkotika Klas IIA Yogyakarta dihuni oleh 206 orang warga binaan. Seluruh warga binaan berjenis kelamin laki-laki karena sejak 2014 warga binaan yang berjenis kelamin perempuan telah dipindahkan ke Lapas Klas IIA, Wirogunan, Yogyakarta. Dari sebanyak 206 orang warga binaan yang ada 34 orang atau sebesar $16.5 \%$ diantaranya sudah meninggal dunia. Cukup tingginya angka kematian warga binaan di lapas ini disebabkan karena sakit, namun demikian penyebab sakitnya warga binaan belum dapat diketahui dengan pasti. Apakah sakitnya dan meninggalnya warga binaan disebabkan karena ketergantungannya terhadap narkotia atau penyebab lainnya belum dapat diketahui secara pasti karena belum adanya penelitian mendalam terhadap hal ini.

Dari data primer yang diolah juga dapat diketahui tingkat pendidikan warga binaan seperti tergambar dalam tabel. Tabel 1 menunjukkan tingkat pendidikan tertinggi adalah pendidikan menengah atas sebanyak 87 orang atau sebesar $42 \%$. Dari pendidikan menengah tersebut sebanyak 5 orang berpendidikan Sekoalah Menengah Kejuruan (STM) dan satu orang berpendidikan Aliyah. Apabila dilihat lebih jauh lagi, mereka yang berpendidikan SMA tersebut saat ini sedang duduk di bangku kuliah. Data ini menunjukkan bahwa tingkat pendidikan warga binaan cukup tinggi. Hal ini menunjukkan bahwa dengan tingkat pendidikan yang cukup tinggi masih dapat terpengaruh dengan narkotika. Artinya, tingkat pendidikan yang tinggi tidak berkaitan langsung dengan adanya kesadaran tentang bahaya narkotika.

Dari tabel 1 juga diperoleh data, tingkat pendidikan yang tidak teridentifikasi cukup tinggi yaitu sebanyak 57 orang atau sebesar $27.6 \%$. Tingginya data pendidikan yang tidak teridentifikasi ini dapat disebabkan oleh beberapa hal. Pertama, disebabkan oleh ketertutupan warga binaan terhadap tingkat pendidikannya, ketika dimintai keterangan oleh petugas, warga binaan tidak bersedia memberikan keterangan tentang tingkat pendidikannya. Kedua, karena memang petugas lalai dalam mencatat dan mengumpulkan informasi mengenai tingkat pendidikan warga binaan. Ketiga, karena memang warga

Tabel 1. Tingkat Pendidikan Warga Binaan

\begin{tabular}{llcc}
\hline No. & $\begin{array}{l}\text { Tingkat } \\
\text { Pendidikan Warga } \\
\text { Binaan }\end{array}$ & Frekuensi & Prosentase \\
\hline 1. & Tidak sekolah & 1 & $0.6 \%$ \\
2. & Sekolah Dasar & 16 & $7.8 \%$ \\
3. & SMP & 31 & $15 \%$ \\
4. & SMA/STM/Aliyah & 87 & $42 \%$ \\
5. & Diploma Tiga & 7 & $3.5 \%$ \\
6. & Sarjana & 7 & $3.5 \%$ \\
7. & Tidak & 57 & $\mathbf{2 7 . 6 \%}$ \\
& teridentifikasi & & $\mathbf{1 0 0}$ \\
\hline
\end{tabular}

Sumber: Bag. Adm. LP Narkotika Yogyakarta, data per 7 Mei 2015 
binaan tidak memiliki tingkat pendidikan tertentu. Dalam hal ini, kemungkinan pertama yang berpeluang lebih besar disebabkan, korban narkotika biasanya adalah orang yang tertutup terhadap identitas dirinya.

Warga binaan yang berpendidikan sarjana dan diploma tiga ada sebanyak 14 orang atau hanya sebesar $7 \%$ saja. Data ini cukup melegakan karena sedikit banyak orang yang berpendidikan tinggi hanya kecil saja terpengaruh oleh narkotika. Hal ini dapat dipergunakan sebagai data awal yang menunjukkan terjadinya hubungan antara pendidikan dengan penggunaan narkoba. Suatu hal yang cukup memprihatinkan, masih terdapat satu orang korban narkoba yang tidak berpendidikan dan masih terdapat 16 orang atau sebesar $7.8 \%$ yang tingkat pendidikannya adalah Sekolah Dasar. Tingkat pendidikan yang rendah ternyata masih cukup rentan terkena pengaruh narkoba. Bisa jadi karena kurangnya pemahaman mengenai bahaya narkoba yang menyebabkan orang-orang ini terjerat dalam ketergantungan narkoba. Data ini sekali lagi memperlihatkan bahaya narkoba dapat menjerat siapa saja, bahkan mereka yang berasal dari kalangan bawah.

Tabel 2 menyajikan tingkatusia warga binaan. Usia yang ada dikategorikan ke dalam enam kategori usia selain usia di bawah 20 tahun dan usia di atas 40 tahun, rentang usia yang dibuat adalah lima tahun. Rentang usia lima tahun ini dibuat untuk dapat merinci kategori usia warga binaan. Kategori ini diperlukan untuk melihat usia sekolah, usia kuliah dan usia produktif dan usia produktif lanjut sampai menjelang pensiun.

Data tabel 2 meperlihatkan pengguna narkoba di usia sekolah dan persiapan kuliah kecil jumlahnya yaitu hanya 4 orang yang berusia di bawah 20 tahun. Data ini cukup melegakan mengingat mereka yang masih di usia sekolah belum banyak yang terkena pengaruh narkoba. Sedangkan data yang cukup memperihatinkan sebagian besar mereka yang terperangkap narkoba adalah mereka yang berada di usia pendidikan kuliah.

Dari Tabel 2 dapat diperoleh informasi penting, pengguna narkoba yang tertangkap sebanyak 54 orang atau sebesar $26.2 \%$ adalah mereka yang dalam usia sangat produktif yaitu di usia 20-25 tahun yaitu di usia menempuh pendidikan di perguruan tinggi. Hal ini sesuai dengan data yang terlihat di tabel 1. Mereka yang berada di usia sma dan di bangku kuliah yang jumlahnya sangat besar. Data ini tentunya sangat memprihatinkan mengingat usia produktif yang seharusnya dimanfaatkan sebaik-baiknya dalam pengembangan diri dan memulai karir justru terjerembab ke dalam penyalahgunaan narkoba.

Seoranginforman yang berasal dariluar Jawa yang diwawancarai dalam penelitian ini adalah seorang mahasiswa semester satu di Jurusan Teknik Arsitektur sebuah Perguruan Tinggi Swasta di Yogyakarta tampak sangat menyesali perbuatannya karena waktu yang seharusnya dipakai untuk menuntut ilmu di bangku kuliah justru harus dihabiskan di balik tembok Lapas yang sangat tertutup.

"saya akan melanjutkan kuliah di Jurusan Arsitektur lagi setelah ke luar dari sini. Saya berjanji pada diri saya sendiri tidak akan mengulangi perbuatan

\section{Tabel 2. Tingkat Usia Warga Binaan}

\begin{tabular}{llcc} 
No. Usia Warga & Frekuensi & Prosentase \\
binaan & & \\
\hline 1. & $\begin{array}{l}\text { Di bawah } 20 \\
\text { tahun }\end{array}$ & 4 & $1.9 \%$ \\
2. & 20 th. -25 th. & 54 & $26.2 \%$ \\
3. & 26 th. -30 th. & 53 & $25.7 \%$ \\
4. & 31 th. -35 th. & 45 & $22 \%$ \\
5. & 36 th. -40 th. & 25 & $12.1 \%$ \\
6. & $\begin{array}{c}\text { Di atas } 40 \text { th. } \\
\text { Jumlah }\end{array}$ & 25 & $12.1 \%$ \\
\hline & $\mathbf{2 0 6}$ & $\mathbf{1 0 0}$ \\
\hline
\end{tabular}


saya. Saya menyesal telah melakukan perbuatan saya menghisap ganja. Kasihan pada orang tua dan saudara-saudara saya yang sudah banyak berkorban untuk kuliah saya".

Pemuda yang berusia 20 tahun ini tampak sekali menyesali perbuatannya dan berniat tidak akan mengulangi perbuatannya lagi. Tapi penyesalannya itu tidak dapat mengurangi hukumannya di balik tembok Lapas. Tapi setidaknya harapan masih terpancar pada pemuda lajang yang diganjar hukuman 1 tahun 2 bulan kurungan itu.

Data tabel 2 juga memperlihatkan, mereka yang diusia produktif lanjut masih cukup besar yaitu $12 \%$ atau sebanyak 20 Orang. Angka ini memperlihatkan bahwa tingkat kematangan dan kedewasaan orang masih tetap dapat terpengaruh oleh narkoba. Narkoba tidak hanya menarik bagi mereka yang diusia produktif, usia kuliah melainkan juga di usia produktif lanjut bahkan di usia pensiun. Mereka yang berada di usia tersebut seharusnya sudah matang tingkat kedewasaannya dan cukup pintar untuk memilih hahal yang merugikan kehidupan, tapi kenyataannya masih terjebak juga di bawah pengaruh narkoba.

Mereka yang di usia produktif justru yang lebih banyak terpengaruh dengan narkoba yaitu usia 31 - 40 tahun ada sebanyak $34.2 \%$ atau sebanyak 70 orang. Data ini sangat memprihatinkan, alasan sebagian dari mereka yang terjebak pada narkoba adalah dalam menjalankan pekerjaannya mereka membutuhkan rangsangan atau dorongan yang diakibatkan oleh narkoba seperti dikemukakan oleh salah satu informan yang bekerja sebagai salah seorang disainer grafis sebagai berikut:

"Saya menggunakan ganja untuk doping di dalam pekerjaan saya yang membutuhkan ide-ide kreatif. Dalam dunia seni seperti yang saya geluti, ide kretif sangat diperlukan. Ide kreatif ini dapat saya peroleh kalau saya di bawah pengaruh ganja". Bekerja rasanya menjadi lebih enak dan lancar".

Lebih parah lagi, informan tersebut justruberanggapan bahwa ganja sebenarnya bukanlah barang haram. Menurutnya, ganja tidak termasuk narkotika yang dapat menimbulkan kecanduan. Karena ganja tidak terbuat dari bahan-bahan kimia, ganja adalah buatan alam seperti halnya rokok. Ganja hanyalah seperti rokok biasa, bahkan di beberapa negara seperti di Belanda, ganja sudah menjadi barang legal. Alasan seperti ini, mulai banyak diyakini oleh pengguna ganja. Indikasi itu terlihat dari adanya gerakan di kalangan generasi muda di masyarakat yang menuntut supaya ganja dijadikan sebagai barang legal. Hal ini tentunya harus menjadi perhatian pemerintah, agar tidak semakin banyak generasi muda yang terjebak dengan pembenaran-pembenaran ini.

Lembaga Pemasyarakatan Narkotika Klas IIA Yogyakarta selain dihuni oleh warga binaan asal Yogyakarta juga terdapat warga binaan yang berasal dari luar Yogyakarta, bahkan luar pulau Jawa. Warga binaan yang berasal dari wilayah Jawa tengah misalnya yang berasal dari Surakarta dan Semarang. Sedangkan warga binaan yang berasal dari luar jawa berasal dari Propinsi Aceh Nangroe Darussalam, Nusa Tenggara Barat dan Nusa Tenggara Timur.

\section{Kondisi Lembaga Pemasyarakatan Narkotika Klas II A Yogyakarta}

Lembaga Pemasyarakatan (Lapas) Narkotika Klas IIA Yogyakarta dibentuk berdasarkan Keputusan Menteri Hukum dan Hak Asasi Manusia Nomor : M.04- PR.07.03 Tahun 2007, Tanggal 23 Pebruari 2007, dengan klasifikasi II A, adalah salah satu Unit Pelaksana Teknis (UPT) di bidang Pemasyarakatan termasuk dalam wilayah kerja Kantor Wilayah Departemen Hukum dan HAM Daerah Istimewa Yogyakarta, berlokasi 
di Jalan Kaliurang Km. 17 Kelurahan Pakembinangun, Kecamatan Pakem, Kabupaten Sleman, Provinsi Daerah Istimewa Yogyakarta, berdiri diatas tanah sultan (Sultan Ground) seluas $30.170 \mathrm{~m} 2$, dengan luas bangunan 8.579,46 $\mathrm{m} 2$ dan mampu menampung kurang lebih 474 orang.

Lembaga ini memiliki visi: pertama memulihkan kesatuan hubungan hidup, kehidupan dan penghidupan warga binaan pemsyarakatan sebagai individu, anggota masyarakat dan makhluk Tuhan Yang Maha Esa (membangun manusia mandiri). Kedua, menanggulangi penyalahgunaan narkotika dan badan adiktif berbahaya (narkoba). Sedangkan misi dari lembaga ini ada dua yakni: melaksanakan pembinaan warga binaan pemasyarakatan dalam kerangka penegakan hukum, pencegahan dan penanggulangan penyalahgunaan narkoba serta pemajuan dan perlindungan hak asasi manusia dan melaksanakan pembinaaan dan pengamanan warga binaan khusus penyalahgunaan narkoba, antara lain dengan melakukan rehabilitasi medik dan sosial.

Tujuan dari keberadaan lembaga ini adalah memberikan pembinaan paripurna kepada warga binaan pemasyarakatan secara terpadu melalui aspek hukum, aspek tmedis, aspek sosial, dan aspek spiritual serta mengembangkan pendidikan dan pelatihan pencegahan dengan penanggulangan penyalahgunaan narkoba. Tujuan berikutnya adalah membentuk warga binaan pemasyarakatan agar menjadi manusia seutuhnya, menyadari kesalahan, memperbaiki diri dan tidak menyalagunakan narkoba sehingga dapat diterima kembali oleh lingkungan masyarakat dapat aktif berperan dalam pembangunan dan dapat hidup secara wajar sebagai warga yang baik dan bertanggung jawab.
Pola Komunikasi dan Pembinaan di Lapas Narakotika Kelas II A Yogyakarta

\section{Pola Komunikasi Informal}

Lapas narkotika klas IIA Yogyakarta mengembangkan pola komunikasi yang mengembangkan tidak adanya diskriminasi terhadap warga binaan. Semua warga binaan diperlakukan sama sesuai dengan hak-hak dasarnya. Komunikasi dalam rangka pembinaan yang demikian sesuai dengan Undang-Undang No. 12 tahun 1995, pada Bab III pasal 15 yang berbunyi: warga binaan wajib mengikuti secara tertib program pembinaan dan kegiatan tertentu. Jadi komunikasi yang sama diperlakukan terhadap semua warga binaan.

Dalam menjalin komunikasi dengan warga binaan, petugas diharapkan dapat menempatkan diri ke dalam tiga posisi: petugas, orang tua dan teman. Posisi sebagai petugas dalam komunikasinya harus tetap dapat menjaga hubungan yang baik dan menegakkan nilai-nilai disiplin. Petugas harus dapat mengetahui batas-batasnya sebagai petugas yang harus menegakkan aturan dan disiplin warga binaannya. Dalam posisi sebagai orang tua, petugas diharapkan dapat mengayomi, melindungi dan memberikan nasehat-nasehat yang sekiranya diperlukan oleh warga binaan. Sedangkan dalam posisinya sebagai teman, petugas harus selalu bersedia menjadi penampung curahan hati warga binaan dalam menghadapi masalahnya. Sebagai teman, petugas harus dapat dipercaya oleh warga binaan untuk paling tidak mendengarkan suara hati, curahan hati, unek-unek atau bahkan kekecewaankekecewaan yang ditumpahkan oleh warga binaan.

Kemampuan untuk menempatkan diri ke dalam tiga posisi inilah yang dapat mendorong terjadinya komunikasi yang baik antara petugas dengan warga binaan. Keberhasilan menjalin komunikasi ini 
dirasakan penting tidak hanya bagi warga binaan melainkan juga bagi petugas sendiri. Mengingat keterbatasan petugas yang ada dibanding dengan jumlah warga binaan, maka untuk menghindari konflik dan bahkan demonstrasi warga binaan yang dapat mengancam keselamatan seluruh penghuni Lapas, sangat penting dibangun komunikasi yang terbuka dan saling menghargai.

Komunikasi yang terbuka dan saling menghargai selain dimulai dengan tiadanya diskriminasi terhadap warga binaan, juga dilakukan dengan mulai memberi kepercayaan kepada para warga binaan. Warga binaan yang dinilai memiliki perilaku yang baik, dipercaya untuk menyelesaikan tugas-tugas tertentu di luar blog yang mereka huni. Pekerjaan yang diberikan seperti menjaga perpustakaan di Lapas, membantu membersihkan ruangruang kantor di dalam Lapas dan menyelesaikan tugas-tugas ringan yang ada seperti membagikan konsumsi bagi sesama warga binaan ketika sedang menyelenggarakan acara-acara tertentu seperti pengajian dan acara-acara lainnya.

Keakraban antara petugas dengan warga binaan telah menghasilkan komunikasi yang saling percaya dan memahami satu sama lain sehingga terbentuklah suasana yang kondusif. Dari pola komunikasi yang dikembangkan warga binaan merasa memiliki kepercayaan dan hubungan baik dengan petugas seperti yang dikemukakan oleh informan berikut ini:

"hubungan kami baik. Bahkan saya sering mempercayakan masalah yang saya hadapi kepada petugas, misalnya saya sering minta petugas menghubungi isteri saya untuk membawakan barangbarang keperluan saya. Saya juga sering meminta petugas untuk menyediakan fasilitas tertentu yang saya butuhkan, karena saya suka melukis, saya minta peralatan melukis dan itu disediakan oleh pihak Lapas".
Hal-hal seperti yang digambarkan oleh informan di atas setidaknya menunjukkan tidak terjadinya komunikasi yang macet antara petugas dengan warga binaan.

Selain kominikasi informal yang dilakukan antara warga binaan dengan petugas di atas, komunikasi juga terjadi melalui program bimbingan dan konseling yang dilakukan untuk kepentingan para napi. Bagi napi yang beragama Kotolik disediakan bimbingan dan konseling yang dilakukan oleh konselor dari luar. Konselor dari luar berasal dari sebuah LSM yang memiliki perhatian terhadap permasalahan warga binaan. Pendekatan relegius yang dipergunakan dalam konseling ini. Warga binaan lebih diberi wawasan religi dalam menyelesaikan permasalahannya. Keekatan dengan Tuhan menjadi pokok penting dalam konseling ini.

\section{Pola Komunikasi Formal dan Pembinaan}

Selain komunikasi informal yang dikembangkan, juga terdapat pola komunikasi formal yang dikembangkan dalam pembinaan terhadap warga binaan. Pelaksanaan pembinaan narapidana di atur di dalam pasal 7 Peraturan Pemerintah No.31 tahun 1999 Tentang Pembinaan dan pembimbingan Warga Binaan Pemasyarakatan yakni: pembinaan narapidana dilaksanakan melalui beberapa tahap pembinaan; dan tahap pembinaan sebagaimana dimaksud dalam ayat (1) terdiri dari tiga tahap, yaitu:tahap awal; tahap lanjutan; dan tahap akhir. Surat Edaran Direktorat Jenderal Pemasyarakatan/Bina Tuna Warga No. KP.10.13/3/31 tentang pemasyarakatan sebagai proses, maka hendaknya disalurkan tahap demi tahap guna menghindari kegagalan dari akibatakibat yang tidak diinginkan.

Tahapan-tahapan pembinaan tersebut dapat dirangkum dalam tahapan sebagai berikut; pertama, narapidana 
yang akan memasuki Lapas hendaknya dikenali dan diketahui dahulu apa kekurangan dan kelebihannya. Apa sebab-sebab sampai dia melakukan tindak pidana, dan lain-lain hal tentang dirinya. Berdasarkan pada pengetahuan seperti itu kemudian dapat dilakukan usaha-usaha pembinaan selanjutnya.

Kedua, seandainya pembinaan narapidana dan hubungan dengan masyarakat telah berjalan selaras selama $1 / 3$ dari masa pidana yang harus dijalani dan menurut pendapat Dewan Pembinaan \{Pemasyarakatan sudah dicapai kemajuan dalam proses maka dapat dipindah ke Lembaga Pemasyarakatan yang tingkat keamanannya menengah. Di tempat yang baru ini narapidanadiberi tanggungjawab yang lebih besar, lebihlebih dalam tanggungjawab terhadap masyarakat luar.

Ketiga, jika sudah dijalani kurang lebih separuh masa pidana yang sebenarnya dan menurut Dewan Pembina Pemasyarakatan (DPP) proses pemsayarakatan telah mencapai kemajuan, baik mengenai narapidana maupun unsur-unsur masyarakat, maka wadah perlu diperluas yaitu dengan usaha asimilasi narapidana pada kehidupan masyarakat luar seperti ikut dalam kegiatan sekolah umum, beribadah berolahraga dll. Keempat, jika sudah menjalani 2/3 dari masa pidana sebenarnya, sedikit (sembilan) bulan dapat dilepaskan dengan pelepasan bersyarat. Pada tahap ini wadah proses pelepasan berupa masyarakat luar yang luas.

\section{Pembinaan di BAPAS (Balai Pemasya- rakatan)}

Pembinaan padamasa prosespelepasan yang dilakukan bagi warga binaan tersebut terselenggara atas kerjasama dengan institusi lain yang bernama Bapas (Balai Pemasyarakatan) Klas I di Yogyakarta. Balai Pemasyarakatan Kelas I Yogyakarta terletak di Jalan Trikora 1 Yogyakarta (sebelah utara Alun-alun Utara Yogyakarta).
Balai Pemasyarakatan

(BAPAS) adalah pranata untuk melaksanakan bimbingan kemasyarakatan, dalam hal ini berbeda dengan Lembaga Pemasyarakatan (LAPAS) dimana LAPAS adalah tempat untuk melaksanakan pembinaan narapidana atau warga binaan dan anak didik pemasyarakatan. Program pembinaan terhadap warga bnaan di LAPAS dan BAPAS agar dapat menjadi manusia yang bertanggungjawab serta tidak mengulangi tindak kejahatan tersebut dan dapat diterima oleh masyarakat, maka mereka diberi bimbingan rohani, bimbingan psikis dan bimbingan kegiatan kerja.

Seseorang yang melakukan pelanggaran hukum termasuk tidak pidana narkotika setelah menjalani pembinaan didalam Pembinaan didalam LAPAS tersebut diperlukan adanya suatu program agar proses pembinaan dapat tercapai. Sedangkan pembinaan yang ada diluar LAPAS di laksanakan oleh Balai Pemasyarakatan (BAPAS), yang dalam Pasal 1 ayat 4 UU No.12 Tahun 1995 tentang Pemasyarakatan, menyatakan bahwa BAPAS adalah suatu pranata untuk melaksanakan bimbingan klien Pemasyarakatan. Balai Pemasyarakatan (BAPAS) sendiri mempunyai tugas dan fungsi menyelenggarakan sebagian dari tugas pokok Direktoral Jendral Pemasyarakatan dalam menyelenggarakan pembimbingan klien pemasyarakatan didaerah. Bentuk dari bimbingan yang diberikan macam-macam, mulai dari pemberian pembinaan tentang agama, keterampilan, sampai pada pembinaan kepribadian. Bimbingan ini diberikan dengan tujuan agar klien dapat hidup dengan baik didalam masyarakat sebagai warga negara serta bertanggungjawab, untuk memberikan motivasi, agar dapat memperbaiki diri sendiri, dan tidak mengulangi kejahatan (residive). Pembimbingan terhadap klien dewasa melputi pembimbingan terhadap nara- 
pidana yang memperoleh Pidana bersyarat, Asimilasi, Pembebasan Bersyarat, Cuti Menjelang Bebas (CMB) dan Cuti Bersyarat (CB), Pidana Pengawasan (Pidwas).

"Sekitar 40 persen klien Balai Pemasyarakatan (Bapas) Kelas I Yogyakarta merupakan pengguna narkoba. Sedangkan klien Bapas yang kembali melakukan tindak pidana cukup kecil, yakni dari 300 klien tiap bulannya hanya 19 klien yang mengulangi tindak pidana. klien dari Bapas adalah nara pidana menjalani bebas bersyarat, cuti bersyarat cuti menjelang bersyarat dan pidana bersyarat. Tiap bulan, rata-rata klien Bapas kelas I Yogya sebanyak 300 orang" (wawancara dengan Kepala Bapas Kelas I Yogyakarta Hardjani Pudji Astini BcIP SSo, 5 Juni 2015).

Terdapat banyak kegiatan untuk membina klien kasus narkoba, misalnya pada akhir bulan Mei 2015 “...sebanyak 50 klien Balai Pemasyarakatan Kelas I Yogyakarta terdiri 45 orang laki-laki dan 5 perempuan melakukan tes urin dan tes darah di Kantor Bapas, Jalan Yogyakarta. Hasil dari tes tersebut dirahasiakan dan menjadi catatan bagi BAPAS dalam upaya penyuluhan lebih lanjut. BAPAS juga bekerjasama dengan Puskesmas Gedongtengen seluruh klien binaan Bapas Kelas I DIY mendapatkan paparan pengetahuan tentang kasehatan Seksual dan penyuluhan bahaya HIV..." (wawancara dengan Kasi Bimbingan Klien Dewasa, Sri Rahayu Prakarsawati, 8 Juni 2015)

Seorang warga binaan ketika mereka keluar dari LAPAS, selanjutnya mereka akan diberi bimbingan oleh BAPAS. Dalam hal pembinaan terhadap klien, pihak BAPAS tidak membeda-bedakan jenis kasus pelanggaran yang dimiliki klien. Setiap klien pada satu bulan pertama diwajibkan apel atau hadir di kantor BAPAS untuk melakukan konseling. Apabila klien tersebut dinilai tertib maka apel atau wajib hadir dikantor BAPAS mulai di beri keringanan dari satu minggu sekali menjadi dua minggu sekali, dan seterusnya sampai pihak klien benar-benar bisa dinilai bagus dalam berorientasi kemasyarakat. Tugas BAPAS dalam membina klien tidak semata-mata memberikan tugas wajib hadir di kantor BAPAS untuk konseling namun pihak klien juga di bekali dengan bimbingan ketrampilan. Salah satunya ialah bimbingan kegiatan kerja bagi klien pemasyarakatan agar ketika mereka tidak lagi menjadi narapidana. Mereka dapat memenuhi kehidupan mereka serta menjadi manusia yang memiliki bekal untuk bertahan hidup. menciptakan lapangan pekerjaan kepada klien agar mendapatkan pekerjaan serta dapat memenuhi kebutuhan hidupnya, yaitu wirausaha membuat telur asin, warung angkringan, sablon, dan lain-lain. Dengan demikian, ketika para klien atau warga binaan keluar dari LAPAS, mereka dapat memilki kemampuan wirausaha.

\section{Komunikasi dalam Pembinaan melalui Konsep Terapeutic Community}

Mulai bulan Mei 2015, Lapas Klas IIA Yogyakarta telah ditunjuk oleh Badan Narkotika Nasional sebagai lapas yang menyelenggarakan konsep rehabilitasi sosial yang disebabkan oleh penyalahgunaan narkoba. Program akan berjalan selama tiga bulan dengan peserta program sebanyak 60 oarang warga binaan.

Penyelenggaraan reahabilitasi yang dilaksanakan di Lembaga Narkotika Klas II Yogyakarta didasarkan pada undang-undang No 35 tahun 2009 dan rehabilitasi bagi warga binaan Pemasyarakatan penyalahgunaan Narkoba di Lapas dan Rutan didasarkan pada Surat Edaran Menteri Hukum dan Hak Asasi Manusia RI Nomor: M.HH-01. PK.01.06.10 tahun 2015 tentang mekanisme pelaksanaan Bagi warga Binaan Pemsyarakatan Penyalahgunaan Narkoba di Lapas dan Rutan dan surat Direktur Jenderal Pemasyarakatan 
Nomor.: PAS.PK.01.06.10-182 tanggal 21 April 2015 perihal petunjuk Pelaksanaan Surat Edaran Menteri Hukum dan HAM RI tentang Mekanisme Pelaksanaan bagi WBP.

\section{Konsep Therapeutic Community}

Konsep Therapeutic Community (TC) adalah suatu metode rahabilitasi sosial yang ditujukan kepada korban penyalahguna napza, yang merupakan sebuah keluarga terdiri dari orang-orang yang mempunyai masalah yang sama dan memiliki tujuan yang sama, yaitu menolong diri sendiri dan sesama yang dipimpin oleh seseorang dari mereka, sehingga terjadi perubahan tingkah laku dari yang negatif ke arah tingkah laku yang positif.

TC adalah sekelompok orang dengan masalah yang sama, yang berkumpul untuk saling bantu dalam mengatasi masalah yang dihadapinya. Dengan kata lain, man helping man to help himself, yaitu seseorang menolong orang lain untuk menolong dirinya. Dalam program TC kesembuhan diciptakan melalui perubahan persepsi/ pandangan alam (the renewal of worldview) dan penemuan diri (self discovery) yang mendorong pertumbuhan dan perubahan.

\section{Simpulan}

Pola komunikasi dan pembinaan dalam rehabilitasi pengguna narkotika di lapas Klas II Yogyakarta terdiri dari dua pola. Pertama, pola komunikasi informal dan pola komunikasi formal. Pola komunikasi informal berlangsung dalam situasi yang akrab, terbuka dan saling menghargai. Pola komunikasi yang dikembangkan seperti ini sangat efektif menjaga kepercayaan warga binaan dengan petugas sehingga terbentuk suasana yang kondusif.

Pola komunikasi yang sifatnya informal juga dilakukan dalam bentuk ceramah-ceramah keagamaan yang terjadwal, bimbingan konseling dengan konselor dari luar Lapas yang hadir seminggu sekali dan kegiatan-kegiatan di luar kamar lainnya. Kegiatan di luar kamar dilakukan lebih pada pengembangan keterampilan dan hobi di bengkelbengkel yang dimiliki oleh Lapas.

Namun pola komunikasi informal ini masih belum bisa menyentuh pada aspek kesadaran warga binaan untuk tidak mengulangi lagi perbuatannya. Komunikasi informal semacam ini, masih hanya berlaku bagi pergaulan seharihari belum menyentuh pada aspek penyadaran. Aspek penyadaran baru dapat digarap melalui pola komunikasi yang lebih formal dan intensif dan terstruktur sifatnya.

Pola komunikasi formal yang intensif dan terstruktur dilakukan dengan dua pendekatan. Pertama dengan pendekatan community base treatment. Kedua dengan terapeutic community. Pendekatan community base treatment adalah dengan memilih beberapa warga binaan yang telah sesuai dengan persyaratan untuk kembali bebas dengan melalui serangkaian wawancara dengan warga binaan dan orang luar atau unsur dari masyarakat yang dianggap dapat menjamin dan mengerti perkembangan warga binaan seandainya mereka bebas. Program ini dikembangkan bersama institusi lain yang dikenal dengan BAPAS. Apabila warga binaan sudah di luar tahanan. Disinilah Bapas akan melakukan pembinaan terhadap warga binaan yang bersangkutan.

Konsep kedua yang dilakukan adalah dengan konsep terapeutic community. Konsep ini masih baru dikembangkan di Lapas Klas II Yogyakarta yaitu baru dimulai pada bulan Mei tahun 2015. Konsep rehabilitasi ini dilakukan selama tiga bulan dengan peserta adalah 60 orang warga binaan yang memenuhi syarat. Persyaratannya adalah: WBP yang masa pidananya 3 (tiga) sampai 6 (enam) bulan, 
atau sedang dalam proses pengusulan cuti Bersyarat (CB), Cuti Menjelang Bebas (CMB) atau sedang dalam proses Pembebasan Bersyarat (PB) dan WPB pengguna berdasarkan hasil assesment. Komunikasi akan berjalan secara inten dengan residen yang merupakan petugas yang mengelola pelatihan ini. Tim residen yang ada bertanggungjawab terhadap penanggungjawab program yang telah ditunjuk oleh Kalapas.

Konsep Therapeutic Community (TC) adalah suatu metode rahabilitasi sosial yang ditujukan kepada korban penyalahguna napza, yang merupakan sebuah keluarga terdiri dari orang-orang yang mempunyai masalah yang sama dan memiliki tujuan yang sama, yaitu menolong diri sendiri dan sesama yang dipimpin oleh seseorang dari mereka, sehingga terjadi perubahan tingkah laku dari yang negatif ke arah tingkah laku yang positif. Implikasi penelitian ini membentuk warga binaan menjadi manusia yang kembali utuh setelah ketergantungannya terhadap narkoba.

\section{Daftar Pustaka}

Cangara, Hafied. 2004. Pengantar Ilmu Komunikasi. Raja Grafindo Persada, Jakarta.

DeVito, Joseph A. 2010. Komunikasi Antar Manusia (Edisi 5). Jakarta: Kharisma Publishing.

Mulyana, Dedy. 2010. Ilmu Komunikasi: Suatu Pengantar. Bandung: PT. Remaja Rosdakarya

Moekijat. 1993. Teori Komunikasi. Bandung: Madar Maju.

Soerjobroto, Bahroedin, 1994. Dasar, Tujuan dan Kedudukan Pemasyarakatan. Yogyakarta: Liberty.
Sudjana, 2000, Dasar-dasar Proses Belajar Mengajar. Bandung: Sinar Baru Agensindo.

Undang-Undang Republik Indonesia Nomor 12 Tahun 1995 tentang Pemasyarakatan.

\section{Jurnal}

Indiyah, Faktor-Faktor Penyebab Penyalahgunaan Napza: Studi Kasus Pada Narapidana Di LP Klas II/A Wirogunan Yogyakarta. Jurnal Kriminologi Indonesia Vol. 4 No. I September 2005 .

Haryanto Dwiatmojo, Pelaksanaan Pidana dan Pembinaan Narapidana Narkotika (Studi terhadap Pembinaan Narapidana di Lembaga Pemasyarakatan Narkotika Klas IIA Yogyakarta). Jurnal Perpektif, Volume XVIII, No. 2 Tahun 2013.

Jurnal Sociodev, FISIP UNTAN. Volume 2 Nomor 2, Agustus 2013.

\section{Internet}

(http://nasional.republika.co.id/ berita/nasional/jawa-tengah-diynasional/13/12/30)

http: / / news.okezone.com / $\mathrm{read} / 2014 / 01 / 23 / 337 / 930885\}$

(http:/ / www.antaranews.com / berita/349418/ polri-ungkap-26561)

(http://www.bnn.go.id/artikel/11535/ narkoba-cederai-anak-bangsa)

(http:/ / dedihumas.bnn.go.id/read/ section/berita/2013/07/25/708/ semangat-bersama)

(http: / / www.tempo.co/read / news/2009/04/28) 